\title{
Honours, awards, appointments
}

\author{
Distinguished scientist \\ Professor Graham Ogden (pictured), of the \\ University of Dundee, has been awarded \\ the 2019 IADR Distinguished Scientist \\ Award in Oral Medicine \& Pathology \\ Research, one of the highest awards in \\ dental research. \\ Professor Ogden was presented with the \\ accolade at the International Association \\ for Dental Research (IADR) 97th General \\ Session \& Exhibition of the IADR, held in \\ Vancouver in June.
}

\section{New Board members}

The Faculty of General Dental Practice (FGDP[UK]) has announced three new Board members, who have each been elected for three-year terms of office: Helen Kaney, Head of Dental Services in Scotland for Dental Protection, was elected to one of two national seats; Eldo Koshy, a prostho-

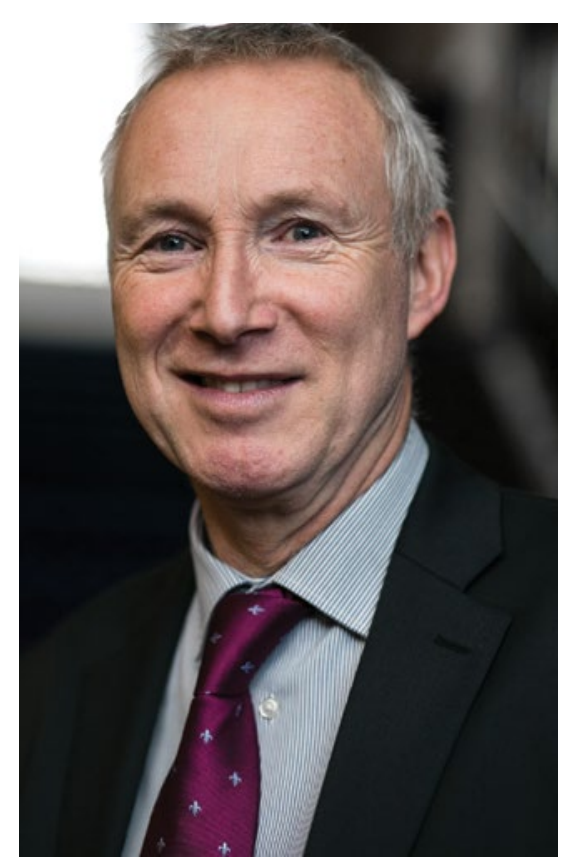

Professor Graham Ogden dontist and implant dentist in Kerala, India, was elected to represent the Faculty's 300 overseas members; and Sami Stagnell, a GDP and specialist oral surgeon, represents the Wessex and Oxford region.

\section{New Vice Deans}

Abhi Pal and Roshni Karia have been inaugurated as the new Vice Deans of the Faculty of General Dental Practice (FGDP[UK]). Abhi has represented the West Midlands on the FGDP(UK) Board since 2014, and becomes Senior Vice Dean. Based in Surrey, Roshni qualified at King's College London in 2010, and is an Associate Dentist in general practice as well as a clinical tutor in periodontology. At 32 Roshni is the Faculty's youngest ever Vice Dean.

\section{New Chair}

Dave Cottam has been elected Chair of the General Dental Practice Committee (GDPC), following a special meeting held at the British Dental Association (BDA) in Wimpole Street Dave, from Birmingham, is a specialist in oral surgery, and previously served as Vice Chair of the GDPC. He will lead negotiations with government over rollout of a reformed GDS contract.

\section{New Hospital Chair}

The Association of Dental Hospitals, which represents the voices of dental hospitals across the UK and Ireland, has elected Professor Tilly Loescher as its new Chair. Professor Loescher is Clinical Director at the Charles Clifford Dental Hospital in Sheffield.

\section{Varshneya Award}

Professor Robert Hill, chair of dental physical sciences at Queen Mary University of London, has received the Varshneya Award for his pioneering research into halogen bioactive glasses for dental applications. Professor Hill, the first British scientist to win this award, was presented with his prize at the 25th International Glass Congress in Boston. The Award was made by the American Ceramic Society.

An expert on fluorine containing glasses and glass-ceramics, Professor Hill was a founder of Biomin Technologies Ltd, who produce BioMin Toothpaste.

\section{Here has been an advertisement.}

SPRINGERNATURE 